\author{
O.V. Sukhova
}

\title{
The Effect of Iron on Precipitation Hardening in the Cu-Ni-Mn Alloys
}

\author{
The Oles' Honchar Dniprovs 'k National University, Dnipro, Ukraine, sukhovaya@ukr.net
}

\begin{abstract}
The peculiarities in the structure and properties formation of precipitation-hardened $\mathrm{Cu}-\mathrm{Ni}-\mathrm{Mn}-\mathrm{Fe}$ alloys within the concentration range of $\mathrm{Ni}(19.3-21.0 \%), \mathrm{Mn}(19.5-20.5 \%), \mathrm{Fe}(0.6-2.7 \%), \mathrm{Cu}-$ balance (in wt. \%) were investigated in this work. The methods of quantitative metallography, X-ray analysis, scanning electron microscopy, energy-dispersive spectroscopy and differential thermal analysis were applied. Two solid solutions based on $\alpha$-Cu differing in composition and hardness were found in the structure of the cast $\mathrm{Cu}-\mathrm{Ni}-\mathrm{Mn}-\mathrm{Fe}$ alloys. The temperature ranges of solutions' formation were determined as $(1010 \pm 10)^{\circ} \mathrm{C}$ and $(890 \pm 10)^{\circ} \mathrm{C}$, correspondingly. NiMn phase was also formed at $(405 \pm 15){ }^{\circ} \mathrm{C}$ due to precipitation hardening. In the $\mathrm{Cu}-\mathrm{Ni}-\mathrm{Mn}-\mathrm{Fe}$ alloys annealed at 500 and $900{ }^{\circ} \mathrm{C}$ for $60-750$ hours, the volume fraction and size of NiMn precipitates increased with prolonging annealing time and lowering annealing temperature. As iron content was raised up to 2.7 wt. \%, the density of NiMn precipitates increased, especially during first 60 hours of annealing at $900{ }^{\circ} \mathrm{C}$. By adding iron, oxidation resistance was improved, but melting temperature and fluidity did not yield any significant change. Hardness of the $\mathrm{Cu}-\mathrm{Ni}-\mathrm{Mn}-\mathrm{Fe}$ alloys with higher iron contents increased by $10 \mathrm{HRB}$ on average. However, when test temperature was raised up to $400{ }^{\circ} \mathrm{C}$, tensile strength decreased (by $\sim 1.3$ times) and elongation dropped markedly (by $\sim 10$ times).

Key words: $\mathrm{Cu}-\mathrm{Ni}-\mathrm{Mn}-\mathrm{Fe}$ alloys, precipitation hardening, annealing, mechanical properties, performance
\end{abstract} characteristics.

Received 2 May 2021; Accepted 10 August 2021.

\section{Introduction}

Copper-containing alloys have gained a variety of applications because of their specific characteristics $[1,2]$. These materials exhibit high mechanical strength at elevated temperatures, good oxidation resistance as well as high corrosion resistance [3-6]. Their usage extends from mechanically and thermally highly stressed parts [7] to corrosion-resistant coatings [8-10].

Most commercial copper alloys usually contain manganese and/or nickel to improve performance characteristics. Nickel has a significant effect on the physical and mechanical properties of $\mathrm{Cu}-\mathrm{Ni}$ alloys [11]. Manganese added to $\mathrm{Cu}-\mathrm{Ni}$ alloys improves casting characteristics and increases strength [12-15]. The cast materials have high fluidity and can reproduce fine details in master patterns, while their good corrosion and oxidation resistance promotes long performance life.

The high strength of the $\mathrm{Cu}-\mathrm{Ni}-\mathrm{Mn}$ alloys is attained by precipitation hardening [16-19]. This process involves the formation of $\theta$-NiMn phase from a supersaturated solid solution of alpha-copper. The precipitation occurs during the cooling of the alloys because the solubility of nickel and manganese in alpha-copper decreases with lowering temperature. The evolution of NiMn precipitates dispersed in the $\alpha-\mathrm{Cu}$ matrix affects the achievement of the material's final strength.

The good characteristic combination of the $\mathrm{Cu}-\mathrm{Ni}-\mathrm{Mn}$ alloys permits their advantageous use as materials for the manufacture of tools and parts for the metallurgy and mining industry, in particular for facing of composite coatings comprising a hard filler phase and $\mathrm{Cu}-\mathrm{Ni}-\mathrm{Mn}$ infiltration alloy of MNMts 20-20-20 grade [20-25]. When commercially fabricated, this infiltration 
alloy contains foreign additives of up to $2.7 \mathrm{wt} \%$ of $\mathrm{Fe}$ [7]. But the carried-out research of the effect of iron on precipitation hardening of the $\mathrm{Cu}-\mathrm{Ni}-\mathrm{Mn}$ alloys has concentrated mainly on the alloys doped with more than 2.7 wt. $\% \mathrm{Fe}$ [26-33]. Although precipitation hardening of the $\mathrm{Cu}-\mathrm{Ni}-\mathrm{Mn}-\mathrm{Fe}$ infiltration alloy may allow wear resistance and mechanical strength desired to special applications of the composite coatings. Moreover, there are many cases of failures involving precipitationhardened materials during their production or operating reported in the literature since incorrect material selection usually associated to these cases [34-38].

Thus, the control of the precipitation of the hardening NiMn phase in the commercially fabricated $\mathrm{Cu}-\mathrm{Ni}-\mathrm{Mn}-\mathrm{Fe}$ infiltration alloys for composite coatings will pave the way for wider applicability of this promising surface strengthening technology [39-42]. Therefore, the effects of iron additives and annealing conditions on changes in microstructure, mechanical properties, and performance characteristics of the precipitation-hardened $\mathrm{Cu}-\mathrm{Ni}-\mathrm{Mn}$ alloys were investigated in this work.

\section{Experimental procedure}

The investigated $\mathrm{Cu}-\mathrm{Ni}-\mathrm{Mn}-\mathrm{Fe}$ alloys were prepared in the following compositional ranges (purity better than $99.9 \%)$ : Ni (19.3 - 21.0 wt. \%), Mn (19.5 20.5 wt. \%), $\mathrm{Fe}(0.6-2.7$ wt. \%), $\mathrm{Cu}-$ the remainder. For the preparation of the specimens, casting technique was employed, such as cooling in the alumina crucibles with a solidification rate of $50{ }^{\circ} \mathrm{C} / \mathrm{min}$.

To characterize some of structural properties, different analytical techniques were applied. Phase constituents and phase morphology were characterized by light-optical microscopy (OM) using NEOPHOT-2 device and scanning electron microscopy by JEOL$2010 \mathrm{~F}$ device equipped with energy-dispersive spectrometer (EDS). The volume fraction of the phases in the alloys was measured by quantitative metallography carried out with EPIQUANT image analyzer. The X-ray diffraction examination was performed using ДРОНУM-1 diffractometer with the $\mathrm{Cu}-\mathrm{K}_{\alpha}$ radiation. The solidification behavior of the alloys was analyzed by differential thermal analysis (DTA) in the temperature range between $20^{\circ} \mathrm{C}$ and $1150{ }^{\circ} \mathrm{C}$ at heating and cooling rates of $10^{\circ} \mathrm{C} / \mathrm{min}$. The uncertainty of the measured temperatures did not exceed $\pm 5^{\circ} \mathrm{C}$. To investigate precipitation hardening, the samples of $\mathrm{Cu}-\mathrm{Ni}-\mathrm{Mn}-\mathrm{Fe}$ alloys were annealed at $500{ }^{\circ} \mathrm{C}$ and $900{ }^{\circ} \mathrm{C}$ for 60 750 hours and then cooled in water to preserve their structure.

Brinell hardness of the alloys was measured by TK$2 \mathrm{M}$ tester. Tensile strength and elongation to failure were determined by standard tests at $20{ }^{\circ} \mathrm{C}$ and $400{ }^{\circ} \mathrm{C}$ using ИМАШ 20-78 stretching machine. Microhardness $\left(\mathrm{H}_{\mu}\right)$ and microbrittleness $(\gamma)$ were measured by ПМТ-3 Vickers indenter. Measurements were done by using $0.196 \mathrm{~N}$ and $0.49 \mathrm{~N}$ loads at room temperature. The loading and unloading times were $10 \mathrm{~s}$ each. After the indention, radial cracks appeared from the corner of the indentation along the direction of the diagonal. The microbrittleness was evaluated from the crack length initiated at the corners of the Vickers microindentation using an equation [43].

Oxidation resistance factor was determined with samples oxidized in air at $300^{\circ} \mathrm{C}$ for 2 hours. Fluidity was measured by spiral fluidity test. In this method, the liquid metal is poured in a mould forming a long thin spiral and the length into which metal is able to run is taken as a measure of the fluidity.

\section{Experimental results and discussion}

Upon cooling, the investigated $\mathrm{Cu}-\mathrm{Ni}-\mathrm{Mn}-\mathrm{Fe}$ alloys at $1000-1020^{\circ} \mathrm{C}$ feature primary crystallization of matrix solid solution based on $\alpha-\mathrm{Cu}$ (referred further as $\alpha-\mathrm{Cu}(1))$ that contains $84-85.4 \% \mathrm{Cu} ; 7.8-9.0 \% \mathrm{Mn}$; $7.3-4.9 \% \mathrm{Ni} ; 0.6-0.7 \% \mathrm{Fe}$ (in wt. \%) (Fig. 1, 2). The solidification temperature of this solution slightly increases with the increase in iron content of the alloys (Table 1).

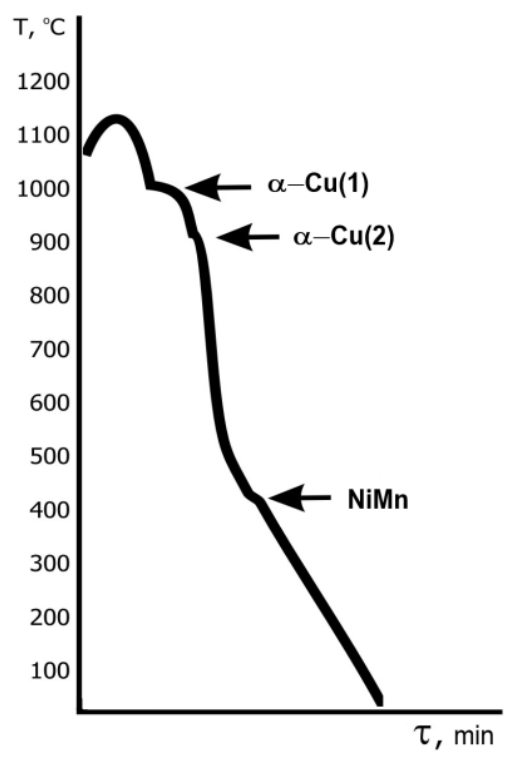

Fig. 1. Cooling curve of $\mathrm{Cu}-21 \% \mathrm{Ni}-20.5 \% \mathrm{Mn}-1.75 \% \mathrm{Fe}$ alloy.

Then, at $880-900{ }^{\circ} \mathrm{C}$ the weak thermal effect attributed to the formation of secondary solid solution based on $\alpha$-copper (referred as $\alpha-\mathrm{Cu}(2)$ ) is observed. Its composition, determined by EDS measurements, is found to fall within the concentration range of 72.3 $77.5 \% \mathrm{Cu} ; 13.1 \%-3.8 \% \mathrm{Ni} ; 8.4-10.5 \% \mathrm{Mn} ; 6.2$ $8.2 \% \mathrm{Fe}$ (in wt. \%). The secondary $\alpha-\mathrm{Cu}(2)$ crystals are distributed among the dendrites of $\alpha-\mathrm{Cu}(1)$ matrix solid solution (Fig. 2, a). Both the phases differ in microhardness $-1.72 \pm 0.1 \mathrm{GPa}$ (matrix solution) and $2.32 \pm 0.2$ ГПа (iron-rich secondary solution). So, the heterogeneous structure occurs in the investigated alloys before precipitation hardening. It may be assumed that appearance of these phases is caused by decomposition of the primary oversaturated solid solution to two solutions based on $\alpha-\mathrm{Cu}$ since the solubility of 


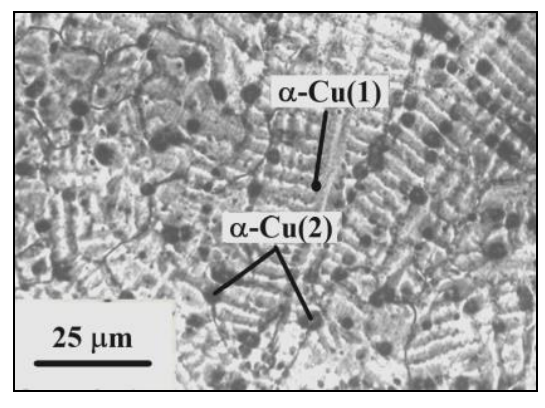

a

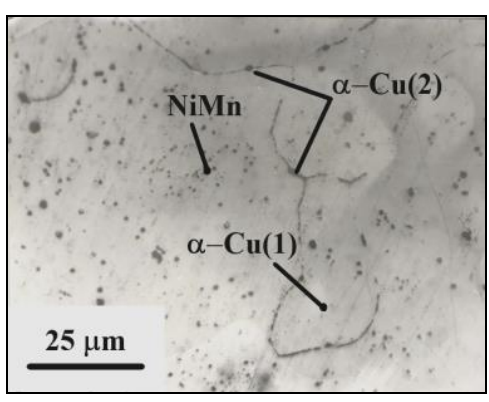

b

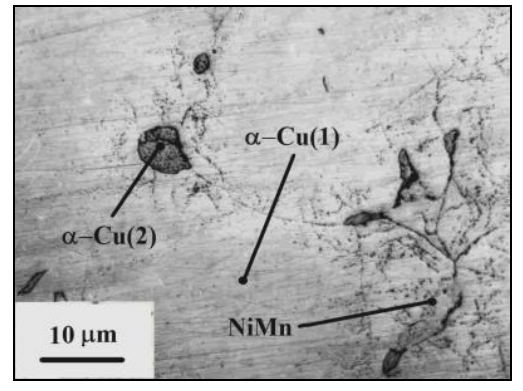

Fig. 2. OM images of $\mathrm{Cu}-19.5 \% \mathrm{Ni}-19.3 \% \mathrm{Mn}-2.7 \% \mathrm{Fe}$ alloy: a - sample etched by $3 \%$ alcohol solution of nitric acid; b, c-non-etched samples.

Table 1

Chemical composition and properties of the investigated $\mathrm{Cu}-\mathrm{Ni}-\mathrm{Mn}-\mathrm{Fe}$ alloys

\begin{tabular}{|c|c|c|c|c|c|c|c|}
\hline \multirow{2}{*}{ Sample } & \multicolumn{4}{|c|}{ Chemical composition, wt. \% } & \multicolumn{1}{c|}{$\begin{array}{c}\text { Melting } \\
\text { temperature, }{ }^{\circ} \mathrm{C}\end{array}$} & $\begin{array}{c}\text { Fluidity, } \\
\mathrm{mm}\end{array}$ & $\begin{array}{c}\text { Oxidation resistance } \\
\text { factor, units }\end{array}$ \\
\cline { 2 - 5 } & $\mathrm{Ni}$ & $\mathrm{Mn}$ & $\mathrm{Fe}$ & $\mathrm{Cu}$ & $1005 \pm 5$ & $440 \pm 5$ & 1.0 \\
\hline No. 1 & 20.5 & 20.0 & 0.6 & balance & $1010 \pm 5$ & $430 \pm 5$ & $1.27 \pm 0.3$ \\
\hline No. 2 & 21.0 & 20.5 & 1.75 & balance & $10 \pm 0.2$ & $1.35 \pm 0.2$ \\
\hline No. 3 & 20.0 & 19.5 & 2.1 & balance & $1015 \pm 5$ & $428 \pm 5$ & $1.41 \pm 0.2$ \\
\hline No. 4 & 20.5 & 19.5 & 2.35 & balance & $1015 \pm 5$ & $430 \pm 5$ & $1.45 \pm 0.1$ \\
\hline
\end{tabular}

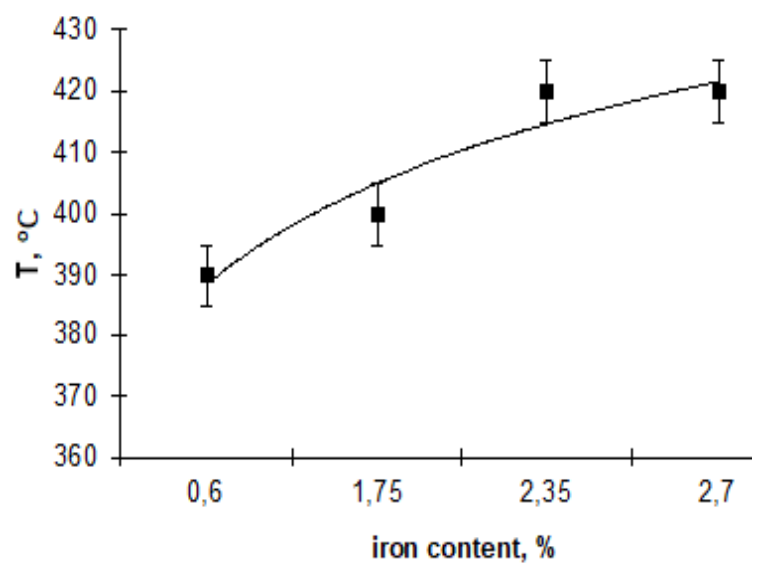

Fig. 3. Starting temperature of NiMn precipitates formation versus the iron content of the $\mathrm{Cu}-\mathrm{Ni}-\mathrm{Mn}-\mathrm{Fe}$ alloys.

components decreases during cooling. With iron content of the alloys raised from 0.6 to $2.7 \mathrm{wt} \%$, a volume fraction of $\alpha-\mathrm{Cu}(2)$ phase increases from approximately 10 to 20 vol. $\%$.
And finally, in the temperature range from 420 to $200{ }^{\circ} \mathrm{C}$ the $\mathrm{Cu}-\mathrm{Ni}-\mathrm{Mn}-\mathrm{Fe}$ alloys produce fine dispersed NiMn phase. This phase is appeared due to precipitation hardening of the $\mathrm{Cu}-\mathrm{Ni}-\mathrm{Mn}-\mathrm{Fe}$ alloys (Fig. 2, b, c) [18]. With increase in the iron content of the alloys, thermal effect corresponding to the start of NiMn formation is shifted to higher temperatures (Fig. 3).

Oxidation resistance factor of the $\mathrm{Cu}-\mathrm{Ni}-\mathrm{Mn}-\mathrm{Fe}$ alloys depends on their composition (Table 1). Iron contents at this level markedly increase resistance to oxidation. As visual observations evidence, iron promotes the formation of an adherent, uniform protective surface layer and thus improves oxidation resistance. The higher iron contents slightly reduce the fluidity of the $\mathrm{Cu}-\mathrm{Ni}-\mathrm{Mn}-\mathrm{Fe}$ alloys (Tabl. 1).

After annealing at $900{ }^{\circ} \mathrm{C}$ for $60-750$ hours, in the structure of all investigated samples, the crystals of $\alpha-\mathrm{Cu}(2)$ secondary phase observed at the grain boundaries of $\alpha-\mathrm{Cu}(1)$ matrix solid solution are found to have non-homogeneous structure. In the interior of this phase of grey color, a light-grey region is seen (Fig. 4).

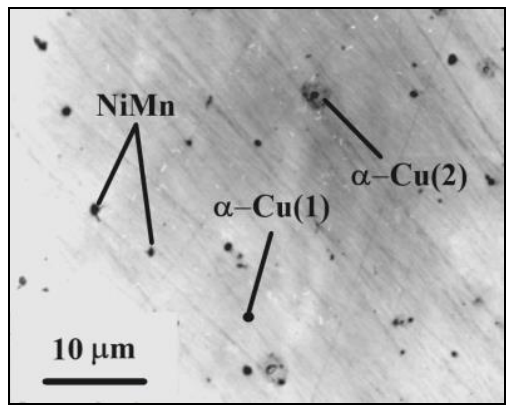

a

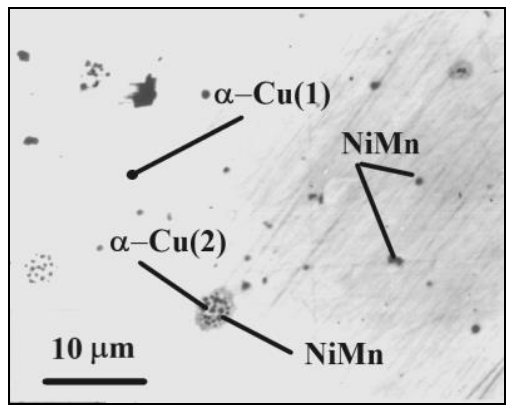

b

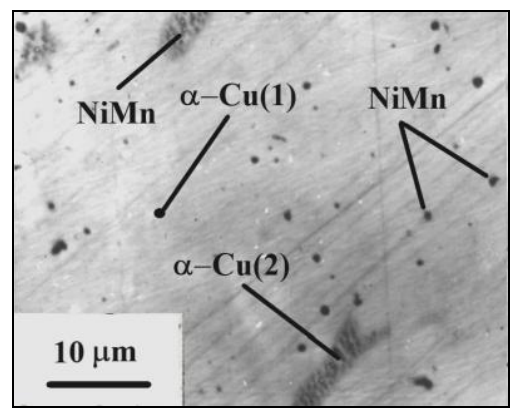

$\mathrm{c}$

Fig. 4. OM images of $\mathrm{Cu}-19.5 \% \mathrm{Ni}-19.3 \% \mathrm{Mn}-2.7 \% \mathrm{Fe}$ alloy after annealing at $900{ }^{\circ} \mathrm{C}$ : a - for 60 hours; $\mathrm{b}$ - for 230 hours; $\mathrm{c}$ - for 750 hours. 


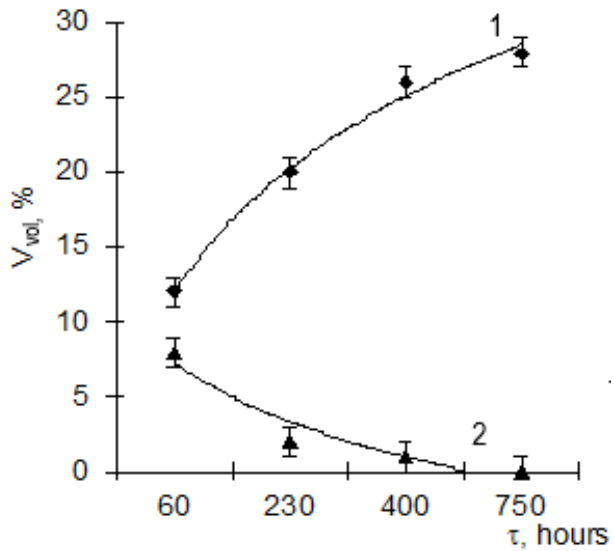

a

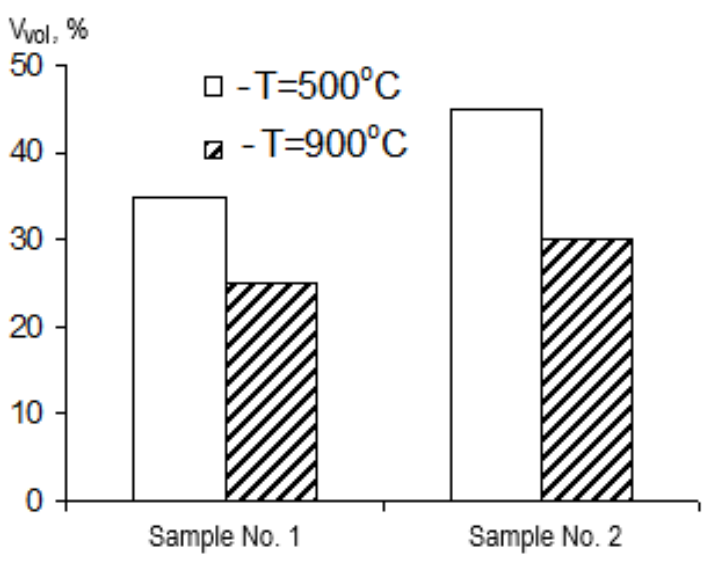

b

Fig. 5. Volume fractions of phases as functions of annealing conditions: a - influence of annealing time on volume fractions of NiMn (curve 1) and secondary solution $\alpha-\mathrm{Cu}(2)$ (curve 2) of sample No. 2 at annealing temperature $900{ }^{\circ} \mathrm{C} ; \mathrm{b}$ - influence of annealing temperature on volume fraction of NiMn precipitates at annealing time 750 hours.

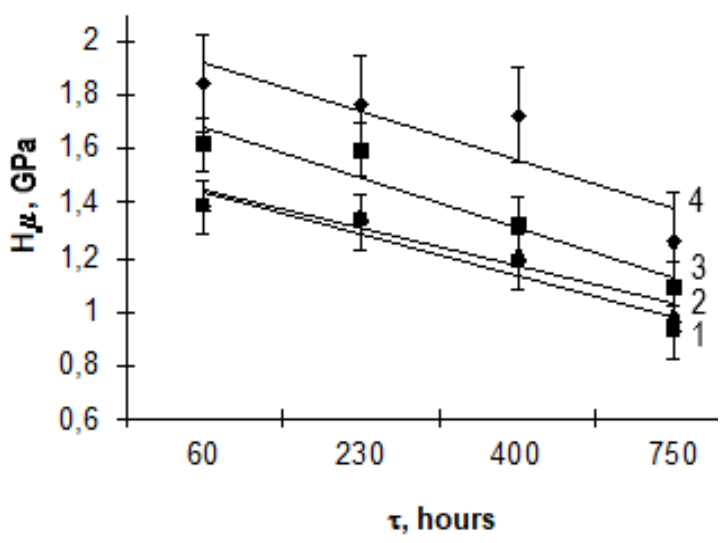

Fig. 6. Microhardness of matrix $\alpha-\mathrm{Cu}$ solution versus annealing time at $900{ }^{\circ} \mathrm{C}: 1-$ sample No. 1; 2 -sample No. 2; 3 - sample No. 3; 4 -sample No. 4.

The increase in the annealing time gives rise to the decrease in the volume fraction of $\alpha-\mathrm{Cu}(2)$ crystals. After annealing for 750 hours, they almost completely disappear (Fig. 5, a, curve 2).

The revealed structural changes may be explained by dissolution of the metastable $\alpha-\mathrm{Cu}(2)$ phase at annealing temperature. As a result, non-homogeneous structure of the globular crystals is observed because in their interior remain the regions of non-dissolved phase. On the periphery of these crystals, solid solution based on $\alpha-\mathrm{Cu}$ contains less iron as compared with the crystals before annealing but more iron than $\alpha-\mathrm{Cu}(1)$ matrix solution.

After annealing at $900{ }^{\circ} \mathrm{C}$, in the structure of the $\mathrm{Cu}-\mathrm{Ni}-\mathrm{Mn}-\mathrm{Fe}$ alloys are also observed the fine precipitates of NiMn phase of dark color (Fig. 4). They are formed both at the grain boundaries and throughout matrix $\alpha$-copper solution. Graphs showing the microhardness of solid matrix $\alpha$-solution as a function of annealing time evidence that all investigated alloys feature precipitation hardening (Fig. 6). There is a clear tendency, the longer annealing time the lower is the microhardness.

As quantitative metallographic and X-Ray analyses indicate, volume fraction and size of NiMn precipitates increase due to precipitation hardening. An average size of precipitates ranges from 5 до $10 \mu$ м. Longer annealing time leads to higher values of volume fraction of NiMn phase (Fig. 5, a, curve 1). As DTA results show, the thermal effect at $\sim 420{ }^{\circ} \mathrm{C}$ attributed to $\mathrm{NiMn}$ precipitation in the $\mathrm{Cu}-\mathrm{Ni}-\mathrm{Mn}-\mathrm{Fe}$ alloys is significantly stronger with increasing NiMn volume fraction.

When iron content of the $\mathrm{Cu}-\mathrm{Ni}-\mathrm{Mn}-\mathrm{Fe}$ alloys is raised, the volume fraction of NiMn phase slightly increases after annealing at $900{ }^{\circ} \mathrm{C}$ for 60 hours and does not noticeably change after annealing for 750 hours (Fig. 7).

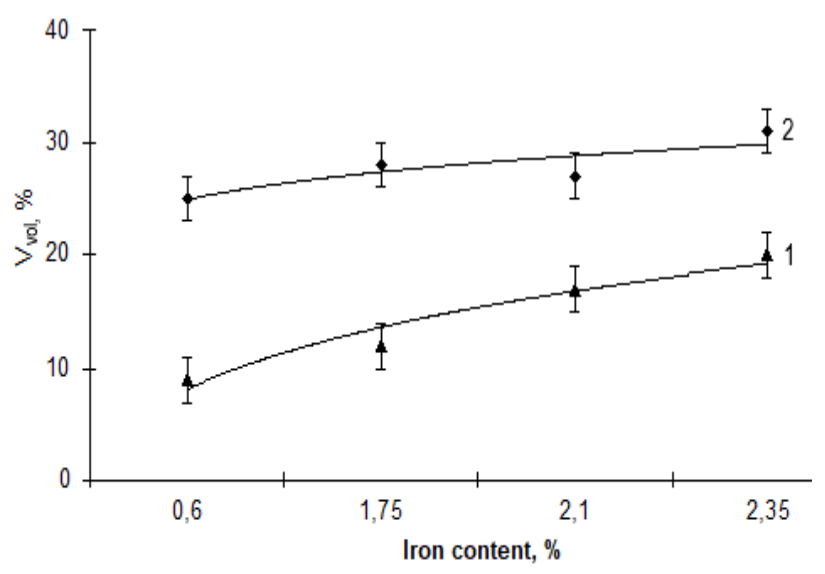

Fig. 7. Volume fraction of NiMn phase versus iron content of the $\mathrm{Cu}-\mathrm{Ni}-\mathrm{Mn}-\mathrm{Fe}$ alloys annealed at $900{ }^{\circ} \mathrm{C}$ for: $1-60$ hours; $2-750$ hours.

Density of NiMn precipitates is higher where $\alpha$ $\mathrm{Cu}(2)$ secondary phase was located before its dissolution during annealing at $900{ }^{\circ} \mathrm{C}$ (Fig. 4, c). Thus, it may be concluded that $\alpha-\mathrm{Cu}(2)$ acts as nucleation site for NiMn precipitates. Addition of up to $2.7 \mathrm{wt}$. \% Fe accelerates the precipitation hardening of the $\mathrm{Cu}-\mathrm{Ni}-\mathrm{Mn}-\mathrm{Fe}$ alloys accompanying by NiMn formation. The effect tends to be more marked after first 60 hours of annealing.

The $\mathrm{Cu}-\mathrm{Ni}-\mathrm{Mn}-\mathrm{Fe}$ alloys. containing up to 2.7 wt. $\% \mathrm{Fe}$ annealed at $500{ }^{\circ} \mathrm{C}$ with following 
quenching in water, exhibit the similar microstructure. Primary $\alpha-\mathrm{Cu}(1)$ matrix solid solution with iron content from 0.6 to 0.7 wt. $\%$, secondary $\alpha-\mathrm{Cu}(2)$ phase with iron content from 6.2 to $8.2 \mathrm{wt}$. \%, and NiMn precipitates are revealed in these alloys (Fig. 8). After annealing at $500{ }^{\circ} \mathrm{C}$, the volume fraction of $\mathrm{NiMn}$ phase that is produced from the matrix increases as compared with that after annealing at $900{ }^{\circ} \mathrm{C}$ for the same period of 750 hours (Fig. 5, b). Iron favors the formation of the NiMn precipitates that have a plate like morphology.

Addition of iron slightly enhances a microhardness of matrix $\alpha$-copper solution before and after annealing (Table 2). In most cases, microbrittleness can be hardly measured because no cracks are seen after indentation. become harder by $12 \%$ on average because more NiMn nucleation sites occur. Annealing at $900{ }^{\circ} \mathrm{C}$ for 500 hours brings about the decrease in Brinell hardness which is possibly connected with overaging of the samples.

Tensile strength at $20^{\circ} \mathrm{C}$ and $400{ }^{\circ} \mathrm{C}$ decreases with increasing iron content and increases upon annealing at $900{ }^{\circ} \mathrm{C}$ for 500 hours (Table 3). After precipitation treatment under the same conditions, elongation at room temperature of sample No. 1 with iron content of 0.6 wt. $\%$ decreases by $3 \%$ (from $\sim 32$ to $\sim 29 \%$ ), elongation of sample No. 2 that contains 1.75 wt. $\% \mathrm{Fe}$ lowers by $5 \%$ (from $\sim 30$ to $\sim 25 \%$ ), and that of sample No. 5 with 2.7 wt. $\% \mathrm{Fe}$ is down by $10 \%$ (from $\sim 23$ to $\sim 13 \%$ ). Elongation measured at temperature of $400{ }^{\circ} \mathrm{C}$ is

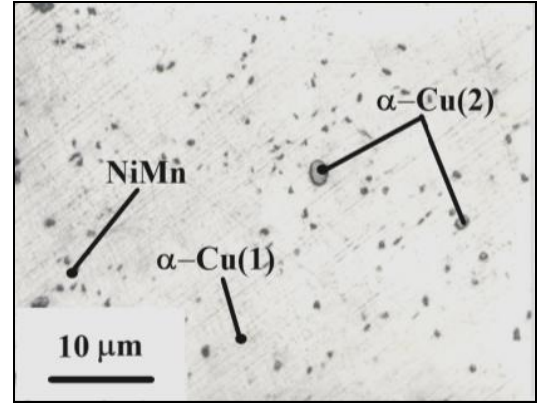

a

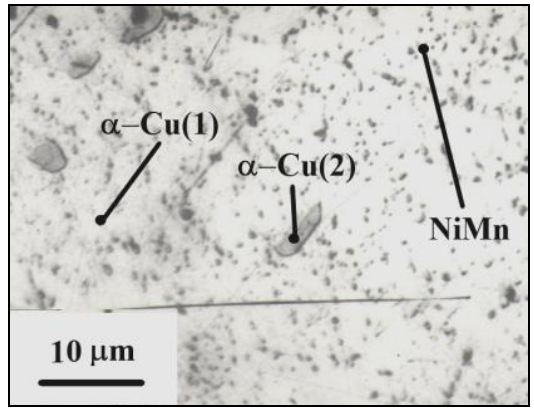

b

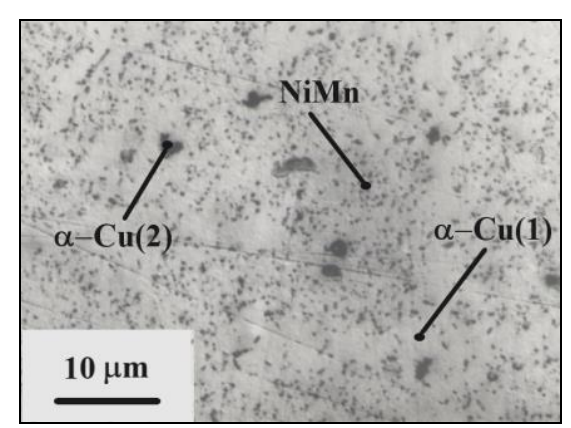

c

Fig. 8. OM images of the $\mathrm{Cu}-\mathrm{Ni}-\mathrm{Mn}-\mathrm{Fe}$ alloys after annealing at $500{ }^{\circ} \mathrm{C}$ for 750 hours: a - sample No. 1; b-sample No. 3; c-sample No. 5.

Table 2

Microhardness (in GPa), microbrittleness (in units) and Brinell hardness (HRB) of the $\mathrm{Cu}-\mathrm{Ni}-\mathrm{Mn}-\mathrm{Fe}$ alloys before and after annealing at $500{ }^{\circ} \mathrm{C}$ and $900^{\circ} \mathrm{C}$ for 500 hours

\begin{tabular}{|c|c|c|c|c|c|c|c|}
\hline \multirow[b]{2}{*}{ Sample } & \multicolumn{2}{|c|}{$\begin{array}{c}\text { Microhardness of matrix } \\
\alpha-\mathrm{Cu} \text { solution }\end{array}$} & \multicolumn{2}{|c|}{$\begin{array}{c}\text { Microbrittleness of matrix } \\
\alpha-\mathrm{Cu} \text { solution }\end{array}$} & \multicolumn{3}{|c|}{ Brinell hardness } \\
\hline & $\begin{array}{l}\text { before } \\
\text { annealing }\end{array}$ & $\begin{array}{c}\text { after } \\
\text { annealing } \\
\text { at } 900{ }^{\circ} \mathrm{C}\end{array}$ & $\begin{array}{l}\text { before } \\
\text { annealing }\end{array}$ & $\begin{array}{c}\text { after } \\
\text { annealing } \\
\text { at } 900{ }^{\circ} \mathrm{C}\end{array}$ & $\begin{array}{c}\text { before } \\
\text { annealing }\end{array}$ & $\begin{array}{c}\text { after } \\
\text { annealing } \\
\text { at } 500{ }^{\circ} \mathrm{C}\end{array}$ & $\begin{array}{c}\text { after } \\
\text { annealing } \\
\text { at } 900^{\circ} \mathrm{C}\end{array}$ \\
\hline No. 1 & $1.71 \pm 0.07$ & $1.09 \pm 0.1$ & no cracks & $0.06 \pm 0.01$ & $61.0 \pm 3.0$ & $65.8 \pm 3.8$ & $46.8 \pm 1.8$ \\
\hline No. 2 & $1.80 \pm 0.11$ & $1.14 \pm 0.21$ & no cracks & no cracks & $67.0 \pm 1.0$ & $76.0 \pm 2.5$ & $54.0 \pm 1.0$ \\
\hline No. 3 & $1.83 \pm 0.1$ & $1.25 \pm 0.07$ & $0.07 \pm 0.05$ & $0.33 \pm 0.02$ & $68.0 \pm 2.0$ & $79.0 \pm 1.0$ & $66.0 \pm 2.8$ \\
\hline No. 4 & $1.85 \pm 0.14$ & $1.37 \pm 0.19$ & no cracks & $0.17 \pm 0.03$ & $70.5 \pm 1.5$ & $77.0 \pm 1.0$ & $67.0 \pm 3.5$ \\
\hline No. 5 & $1.87 \pm 0.2$ & $1.48 \pm 0.12$ & no cracks & no cracks & $72.5 \pm 0.5$ & $81.0 \pm 1.0$ & $71.0 \pm 4.3$ \\
\hline
\end{tabular}

Table 3

Tensile strength (in MPa) and elongation (in \%) of the $\mathrm{Cu}-\mathrm{Ni}-\mathrm{Mn}-\mathrm{Fe}$ alloys before and after annealing at $900{ }^{\circ} \mathrm{C}$ for 500 hours

\begin{tabular}{|c|c|c|c|c|c|c|c|c|}
\hline \multirow{3}{*}{ Sample } & \multicolumn{4}{|c|}{ Tensile strength } & \multicolumn{4}{|c|}{ Elongation } \\
\hline & \multicolumn{2}{|c|}{$\begin{array}{c}\text { Test temperature } \\
20^{\circ} \mathrm{C}\end{array}$} & \multicolumn{2}{|c|}{$\begin{array}{c}\text { Test temperature } \\
400{ }^{\circ} \mathrm{C} \\
\end{array}$} & \multicolumn{2}{|c|}{$\begin{array}{l}\text { Test temperature } \\
20^{\circ} \mathrm{C} \\
\end{array}$} & \multicolumn{2}{|c|}{$\begin{array}{c}\text { Test temperature } \\
400{ }^{\circ} \mathrm{C} \\
\end{array}$} \\
\hline & $\begin{array}{c}\text { before } \\
\text { annealing }\end{array}$ & $\begin{array}{c}\text { after } \\
\text { annealing }\end{array}$ & $\begin{array}{c}\text { before } \\
\text { annealing }\end{array}$ & $\begin{array}{c}\text { after } \\
\text { annealing }\end{array}$ & $\begin{array}{c}\text { before } \\
\text { annealing }\end{array}$ & $\begin{array}{c}\text { after } \\
\text { annealing }\end{array}$ & $\begin{array}{c}\text { before } \\
\text { annealing }\end{array}$ & $\begin{array}{c}\text { after } \\
\text { annealing }\end{array}$ \\
\hline No. 1 & $654 \pm 5.7$ & $664 \pm 6.2$ & $450.8 \pm 39.2$ & $480.2 \pm 9.8$ & $32.6 \pm 0.3$ & $29.7 \pm 0.9$ & $16.0 \pm 0.4$ & $15.3 \pm 0.7$ \\
\hline No. 2 & $637.0 \pm 10.8$ & $656.6 \pm 7.8$ & $359.7 \pm 23.5$ & $394.4 \pm 13.7$ & $30.2 \pm 0.2$ & $25.1 \pm 0.8$ & $4.7 \pm 0.4$ & $1.3 \pm 0.5$ \\
\hline No. 5 & $555 \pm 8.9$ & $568.4 \pm 3.9$ & $338.1 \pm 34.3$ & $423.4 \pm 23.5$ & $23.3 \pm 0.7$ & $13.0 \pm 0.3$ & $2.7 \pm 0.1$ & $1.5 \pm 0.5$ \\
\hline
\end{tabular}

Therefore, unequivocal dependencies of this characteristic on iron concentration of the alloys and annealing temperature have not been established.

Brinell hardness of the $\mathrm{Cu}-\mathrm{Ni}-\mathrm{Mn}-\mathrm{Fe}$ alloys increases as the iron content increases (Table 2). Besides, after annealing at $500{ }^{\circ} \mathrm{C}$ for 500 hours the alloys further reduced from $\sim 15 \%$ up to $\sim 1.5 \%$ (by 10 times) as iron concentration of the $\mathrm{Cu}-\mathrm{Ni}-\mathrm{Mn}-\mathrm{Fe}$ alloys increases from 0.6 to 2.7 wt. \%. These results evidence that iron has negative effect on ductility characteristics of the $\mathrm{Cu}-\mathrm{Ni}-\mathrm{Mn}-\mathrm{Fe}$ alloys, especially when test temperature is raised up to $400{ }^{\circ} \mathrm{C}$. 


\section{Conclusions}

The obtained results evidence that in the structure of the investigated cast $\mathrm{Cu}-\mathrm{Ni}-\mathrm{Mn}-\mathrm{Fe}$ alloys two solid solutions based on $\alpha-\mathrm{Cu}$ are observed, one of which crystallizes from the liquid at $(1010 \pm 10){ }^{\circ} \mathrm{C}$ and another one forms due to limited solubility of the components at $(890 \pm 10)^{\circ} \mathrm{C}$. The secondary solid solution contains more iron and has higher microhardness as compared with primary solid solution. In addition, in the temperature range of $(405 \pm 15){ }^{\circ} \mathrm{C}$, the $\mathrm{NiMn}$ phase precipitates through ageing of the alloys.

Addition of up to $2.7 \mathrm{wt}$ \% $\mathrm{Fe}$ to the $\mathrm{Cu}-\mathrm{Ni}-\mathrm{Mn}$ alloys exhibits no substantial effect on such technological characteristics as melting temperature and fluidity. The increase in iron content enhances hardness and oxidation resistance of the $\mathrm{Cu}-\mathrm{Ni}-\mathrm{Mn}-\mathrm{Fe}$ alloys. However, at that, tensile strength and elongation deteriorate. Negative effect of iron increases as test temperature is raised up to $400{ }^{\circ} \mathrm{C}$.

Upon annealing at $500{ }^{\circ} \mathrm{C}$ and $900{ }^{\circ} \mathrm{C}$ for $60-$ 750 hours, the secondary solid solution based on $\alpha-\mathrm{Cu}$ is re-dissolved into the matrix of $\alpha-\mathrm{Cu}$. More NiMn precipitates appear as the annealing time increases. It can be judged that the precipitates are likely generated at lower annealing temperature. Besides, the higher concentrations of iron added to the $\mathrm{Cu}-\mathrm{Ni}-\mathrm{Mn}$ alloys accelerate processes of precipitation hardening during first 60 hours of annealing, and then iron practically does not affect the rate of $\mathrm{NiMn}$ precipitation. Iron is beneficial for obtaining more precipitated phases because the number of nucleation sites increases during the precipitation process.

Annealing at $500{ }^{\circ} \mathrm{C}$ for 500 hours enhances Brinell hardness of the $\mathrm{Cu}-\mathrm{Ni}-\mathrm{Mn}-\mathrm{Fe}$ alloys by $12 \%$ on average. The tensile strength of the alloys annealed at $900{ }^{\circ} \mathrm{C}$ for 500 hours increases (by $15 \%$ on average), but elongation decreases (by 1.9 times on average), especially with increasing iron content of the alloys.

Thus, the $\mathrm{Cu}-\mathrm{Ni}-\mathrm{Mn}-\mathrm{Fe}$ alloys containing up to 2.7 wt. \% may be applied as binder materials for composite coatings provided that working temperature does not exceed $400{ }^{\circ} \mathrm{C}$ and temperature-and-time parameters of infiltration are strictly observed to avoid excessive iron contents.

Sukhova O.V. - Full Professor, Dr Sci Eng., Professor of Experimental Physics Chair.

[1] A.M. Zakharov, Industrial Non-Ferrous Metal Alloys (Metallurgy, Moscow, 1980).

[2] O.V. Sukhova, V.A. Polonskyy, K.V. Ustinova, Metallofizika i Noveishie Tekhnologii 40(11), 1475 (2018); https://doi.org/10.15407/mfint.40.11.1475.

[3] M. Schutze, R. Feser, R. Bender, Corrosion Resistance of Copper and Copper Alloys (Wiley-VCH, Weinheim, 2011).

[4] O.V. Sukhova, V.A. Polonskyy, K.V. Ustinova, Voprosy Khimii i Khimicheskoi Tekhnologii 6(121), 77 (2018); https://doi.org/10.32434/0321-4095-2018-121-6-77-83.

[5] S.R. Wright, F.H. Cocks, L. Gettleman, Journal of Dental Research 59(4), 708 (1980); https://doi.org/10.1177/00220345800590040701.

[6] O.V. Sukhova, V.A. Polonskyy, K.V. Ustinova, Materials Science 55(2), $285 \quad$ (2019); https://doi.org/10.1007/s11003-019-00302-2.

[7] M. Naboka, J. Giordano, Copper Alloys: Preparation, Properties and Applications (Nova Science Publishers Inc., UK, 2013).

[8] S. Sharma, X.N. Dong, P. Wei, C. Long, Key $\quad$ Engineering $\quad$ Materials $\quad 837, \quad 102 \quad$ (2020); https://doi.org/10.4028/www.scientific.net/KEM.837.102.

[9] S.I. Ryabtsev, V.A. Polonskyy, O.V. Sukhova, Powder Metallurgy and Metal Ceramics 58(9-10), 567 (2020); https://doi.org/10.1007/s11106-020-00111-2.

[10] V.G. Efremenko, Yu.G. Chabak, K. Shimizu, A.G. Lekatou, V.I. Zurnadzhy, A.E. Karantzalis, H. Halfa, $\begin{array}{llllll}\text { V.A. Mazur, } & \text { B.V. } & \text { Efremenko, } & \end{array}$ https://doi.org/10.1016/j.matdes.2017.04.022.

[11] J.P. Chubb, J. Billingham, Journal of Metals 30, 20 (1978); https://doi.org/10.1007/BF03354350.

[12] W.H. Sun, H.H. Xu, Y. Du, S.H. Liu, Computer Coupling of Phase Diagrams and Thermochemistry 33(4), 642 (2009); https://doi.org/10.1016/j.calphad.2009.07.003.

[13] P.M. Prysyazhnyuk, Metallurgical and Mining Industry 12, 346 (2015).

[14] V.E. Bazhenov, M.V. Pikunov, V.V. Cheverikin, Metallurgical and Materials Transactions A 46, 843 (2015); https://doi.org/10.1007/s11661-014-2648-8.

[15] E. Schuermann, B. Prinz, Zeitschrift für Metallkunde 65(9), 593 (1974).

[16] H. Kang, Z. Yang, X. Yang, J. Li, W. He, Z. Chen, E. Guo, L.-D. Zhao, T. Wang, Materials Today Physics 17, 100332 (2020); https://doi.org/10.1016/j.mtphys.2020.100332.

[17] R. Wang, Y. Fu, G. Xie, Z. Hao, S. Zhang, X. Liu, Metals 10, 1528 (2020); https://doi.org/10.3390/met10111528.

[18] W. Xie, Q. Wang, X. Mi, G. Xie, D. Liu, X. Gao, Y. Li, Transactions of Nonferrous Metals Society of China 25(10), 3247 (2015); https://doi.org/10.1016/s1003-6326(15)63960-7.

[19] M. Miki, S. Hori, Journal of The Japan Institute of Metals and Materials 46(3), 301 (1982); https://doi.org/10.23333320/jinstmet1952.46.3_301.

[20] I.M. Spiridonova, O.V. Sukhova, A.P. Vashchenko, Metallofizika i Noveishie Tekhnologii 21(2), 122 (1999).

[21] I.M. Spiridonova, E.V. Sukhovaya, V.F. Butenko, A.P. Zhudra, A.I. Litvinenko, A.I. Belyi, Powder Metallurgy and Metal Ceramics 32(2), 139 (1993) (https://doi.org/10.1007/BF00560039). 
[22] P.M. Brune, Masters Theses, 7850 (2017); https://scholarsmine.mst.edu/masters theses /7850.

[23] I.M. Spiridonova, E.V. Sukhovaya, S.B. Pilyaeva, O.G. Bezrukavaya, Metallurgical and Mining Industry 3, 58 (2002).

[24] O.V. Sukhova, Y.V. Syrovatko, Metallofizika i Noveishie Tekhnologii 33(Special Issue), 371 (2011).

[25] T.A. Shihab, L.S. Shlapak, N.S. Namer, P.M. Prysyazhnyuk, O.O. Ivanov, M.J. Burda, Journal of Physics Conference Series 1741, 012031 (2021); https://doi.org/10.1088/1742-6596/1741/1/012031.

[26] J. Zou, L. Shi, H. Shi, Q. Feng, S. Liang, Materials Research Express 7, 056504 (2020); https://doi.org/10.1088/2053-1591/ab8bld.

[27] N. Koji, S. Shairo, Technical Reports of Sumitomo Light Metals 22(1-2), 22 (1981).

[28] P. Sakiewicz, R. Nowosielski, R. Babilas, Indian Journal of Engineering and Materials Sciences 22(4), 389 (2015).

[29] S. Hocker, P. Binkele, S. Schmauder, Applied Physics 115, 679 (2014); https://doi.org/10.1007/s00339-013-7850-9.

[30] Y. Wang, J. Yin, X. Liu, R. Wang, H. Hou, J. Wang, Progress in Natural Science: Materials International 27(4), 460 (2017); https://doi.org/10.1016/j.pnsc.2017.06.005.

[31] N. Taiji, H. Mitsuhiro, Journal of Iron and Steel Institute 67(14), 2085 (1981).

[32] V.G. Rivlin, G.V. Raynor, International Metals Review 28(1), 23 (1983); https://doi.org/10.1179/imtr.1983.28.1.23.

[33] S. Reeh, D. Music, M. Ekholm, I. Abrikosov, J.M. Schneider, Physical Review B. Condensed Matter and Materials Physics 87, 22 (2013); https://doi.org/10.1103/PhysRevB.87.224103.

[34] O.V. Sukhova, K.V. Ustinova, Functional Materials 26(3), 495 (2019); https://doi.org/10.15407/fm26.03.495.

[35] O.P. Ostash, V.V. Kulyk, T.M. Lenkovskiy, Z.A. Duriagina, V.V. Vira, T.L. Tepla, Archives of Materials Science and Engineering 90(2), 49 (2018); https://doi.org/10.5604/01.3001.0012.0662.

[36] A.P. Vashchenko, I.M. Spiridonova, E.V. Sukhovaya, Metallurgia 39(2), 89 (2000).

[37] Z. M. Rykavets, J. Bouquerel, J.-B. Vogt, Z. A. Duriagina, V. V. Kulyk, T. L. Tepla, L. I. Bohun, T. M. Kovbasyuk, Progress in Physics of Metals 20(4), 620 (2019); https://doi.org/10.15407/ufm.20.04.620.

[38] Z.A. Duryagina, S.A. Bespalov, A.K. Borysyuk, V.Ya. Pidkova, Metallofizika i Noveishie Tekhnologii 33(5), 615 (2011).

[39] I.M. Spyrydonova, O.V. Sukhova, G.V. Zinkovskij, Metallurgical and Mining Industry 4(4), 2 (2012).

[40] P.M. Prysyazhnyuk, T.A. Shihab, V.H. Panchuk, Materials Science 52(11), 188 (2016); https://doi.org/10.1007/s11003-016-9942-0.

[41] O.V. Sukhova, Y.V. Syrovatko, Metallofizika i Noveishie Tekhnologii 41(9), 1171 (2019); https://doi.org/10.15407/mfint.41.09.1171.

[42] Yu.D. Myshko, V.G. Nechyporenko, A.N. Gladchenko, N.V. Matkovskyy, N.E. Gonchak, Chemical and Oil Machine Building 6, 28 (1983).

[43] G.V. Samsonov, Yu.G. Tkachenko, V.F. Berdikov, Carbides and Carbide-Based Alloys (Naukova dumka, Kyiv, 1976).

О.В. Сухова

\title{
Вплив заліза на дисперсійне твердіння в сплавах $\mathrm{Cu}-\mathrm{Ni}-\mathrm{Mn}$
}

\author{
Дніпровський національний університет імені Олеся Гончара, Дніпро, Украӥна, sukhovaуa@ukr.net
}

В роботі досліджено закономірності формування структури і властивостей дисперснотвердних сплавів $\mathrm{Cu}-\mathrm{Ni}-\mathrm{Mn}-\mathrm{Fe}$ в концентраційному діапазоні $\mathrm{Ni}(19.3-21.0 \%), \mathrm{Mn}(19.5-20.5 \%), \mathrm{Fe}(0.6-2.7 \%), \mathrm{Cu}-$ залишок (у ваг. \%). Використано методи кількісного металографічного, рентгеноструктурного, сканувального електронно-мікроскопічного, мікрорентгеноспектрального і диференційного термічного аналізів. Встановлено, що в структурі литих сплавів $\mathrm{Cu}-\mathrm{Ni}-\mathrm{Mn}-\mathrm{Fe}$ присутні два твердих розчини на основі $\alpha-\mathrm{Cu}$, які різняться вмістом компонентів і мікротвердістю. Визначено температурні інтервали утворення цих розчинів: $(1010 \pm 10){ }^{\circ} \mathrm{C}$ i $(890 \pm 10){ }^{\circ} \mathrm{C}$, відповідно. Крім того, в структурі за температури $(405 \pm 15){ }^{\circ} \mathrm{C}$ виділяється фаза NiMn внаслідок дисперсійного твердіння сплавів. Після відпалу за температур 500 i $900{ }^{\circ} \mathrm{C}$ протягом 60 750 годин, об'ємна частка і розміри цієї фази збільшуються 3 подовженням тривалості і зниженням температури відпалу. При підвищенні вмісту заліза до 2,7 ваг. \% густина виділень фази NiMn збільшується, особливо, протягом перших 60 годин відпалу за $900{ }^{\circ} \mathrm{C}$. Збільшення вмісту заліза покращує окалиностійкість і практично не впливає на температуру плавлення і рідкоплинність сплавів $\mathrm{Cu}-\mathrm{Ni}-\mathrm{Mn}-\mathrm{Fe}$. Твердість сплавів $\mathrm{Cu}-\mathrm{Ni}-\mathrm{Mn}-\mathrm{Fe} 3$ підвищенням вмісту заліза збільшується в середньому на $10 \mathrm{HRB}$. Однак, за температури випробувань $400{ }^{\circ} \mathrm{C}$ погіршуються міцність на розтяг (в 1.3 рази) і відносне видовження (в 10 разів).

Ключові слова: сплави $\mathrm{Cu}-\mathrm{Ni}-\mathrm{Mn}-\mathrm{Fe}$, дисперсійне твердіння, відпал, механічні властивості, технологічні характеристики. 